J. Appl. Glycosci., 52, 393-398 (2005)

(C) 2005 The Japanese Society of Applied Glycoscience

Regular Paper (in Japanese with English Abstract)

\title{
Comparative Study on Structures of Three Hayadakimai Products Produced with Different Heating Conditions
}

(Received March 2, 2005 ; Accepted June 8, 2005)

\author{
Kazuya Kohayakawa, ${ }^{1, *}$ Yoshio Nishida, ${ }^{2}$ Masanari Asano, ${ }^{3}$ Nobuko Yoshio, ${ }^{4}$ Iwao Maeda, \\ Makoto Hisamatsu ${ }^{5}$ and Hajime Taniguchi ${ }^{6}$
}

\author{
${ }^{1}$ Aichi Industrial Technology Institute (Nishishinwari, Hitotsugi, Kariya 448-0003, Japan) \\ ${ }^{2}$ Food Research Center, Aichi Industrial Technology Institute (2-1-1, Shinnpukuji-cho, Nishi-ku, Nagoya 451-0083, Japan) \\ ${ }^{3}$ Asano Food CO, LTD. (3-43, Syoumei-cho, Nakagawa-ku, Nagoya 454-0855, Japan) \\ ${ }^{4}$ Aichi Konan Junior University (172, Ohmatsubara, Takaya-cho, Konan 483-8086, Japan) \\ ${ }^{5}$ Faculty of Bioresources, Mie University (1515, Kamihama-cho, Tsu 514-8507, Japan) \\ ${ }^{6}$ Bioscience and Biotechnology, Chubu University (1200, Matsumoto-cho, Kasugai 487-8501, Japan)
}

\begin{abstract}
Hayadakimai is a briefly cooked rice product with an appearance similar to that of uncooked rice. It requires only a short time cooking before serving without the washing and soaking processes essential for serving uncooked rice. Morphological, rheological and sensory properties of three commercial Hayadaikimai products manufactured by different heating processes were studied in comparison with uncooked rice. On soaking in water, grains of Hayadakimai products absorbed water to a higher extent than uncooked rice. In the surface layers of Hayadakimai grains, gelatinized starch filled up endosperm cells whereas in interior parts of grains, starch gelatinized only partly and maintained granular structures. There were significant differences among three types of Hayadakimai products in the extent of water absorption at $50^{\circ} \mathrm{C}$ and in the retaining of crystal structure of starch. There was a correlation between the difference of water absorption and disappearance of the crystal structure. These differences were discussed in relation to the cooking time and the amount of water required for cooking of three types of Hayadakimai.
\end{abstract}

Key words: partial-cooked rice (Hayadakimai), water absorption, granule structure, RVA

\section{製造方法の異なる早炊き米の粒構造に及ぼす加熱条件の影響}

\author{
小早川和也 ${ }^{1, *}$ ，西田淑男 ${ }^{2}$, 浅野正成 ${ }^{3}$ ，吉尾信子 ${ }^{4}$ ，前田 嚴 ${ }^{4}$, 久松 眞 $^{5}$, 谷口 肇 ${ }^{6}$ \\ 1 愛知県産業技術研究所（448-0003 刈谷市一ツ木町西新割） \\ 2 愛知県産業技術研究所食品工業技術センター (451-0083 名古屋市西区新福寺町 2-1-1) \\ ${ }^{3}$ 株式会社アサノ食品 (454-0855 名古屋市中川区昭明町 3-43) \\ 4 愛知江南短期大学 (483-8086 江南市高屋町大松原 172) \\ 5 三重大学生物資源学部（514-8507 津市上浜町 1515） \\ ${ }^{6}$ 中部大学応用生物学部（487-8501 春日井市松本町 1200)
}

コメの生産・消費量が世界的に増加する中で日本の生 産・消費量はこの 40 年間にほぼ $2 / 3$ に減少し，世界にお ける生産・消費のシェアは 7.8\%（1960 年) から 2.0\%(2004 年）となりコメの年間消費量も世界平均とほほ同程度の $61.9 \mathrm{~kg} /$ 人 (平成 15 年度) ${ }^{1)}$ と 30 年前の $1 / 2$ にまで減少し ている。一方，簡便性や健康志向など消費者ニーズにマッ チした加工米飯（無菌充填米飯，レトルト米飯，冷凍米飯 など), 加工米 (胚芽米, 発芽玄米, 無洗米など) の生産 品目，数量は増加し ${ }^{2}$, 米加工品の市場は活況を呈してい る.

加工米飯は加熱調理済みで，澱粉は糊化しており，水分 も炊飯米並みの $60 \%$ 以上あり, 調理時間はほとんど不要 である。一方，加工米は未加熱で，水分も精白米と同程度

\footnotetext{
* Corresponding author (Tel. +81-566-24-1841, Fax. +81-566-
} 22-8033, E-mail: kazuya_kohayakawa@pref.aichi.lg.jp)
の $14 \%$ 前後のため, 洗米, 浸漬，炊飯，蒸らしの一連の工 程が必要で，90-120 分程度の調理時間を必要とする。「早 炊き米」は，加工米飯と加工米の中間的な半調理米（水分 量 30-35\% 程度，糊化度 45-80\% 程度）で，洗米・浸漬が 不要で炊飯時間も約 $1 / 2$ と短く, 調理時間は従来法の $1 / 3$ 以下の 25-30 分程度に短縮することが可能な商品として開 発された。早炊き米は十分に吸水させた精白米に短時間の 加熱処理を施すことにより製造されており，加熱方法も蒸 煮処理 ${ }^{3,4)}$, 熱風処理 ${ }^{5)}$ ，レトルト処理(6)などが考案され，そ れぞれの商品が市販されている。

著者らは前報》で，蒸煮処理早炊き米の浸漬時の吸水量 は精白米と異なり温度とともに増加し, 浸漬温度 $50^{\circ} \mathrm{C}$ で は精白米平衡水分量 30\% に対し $64 \%$ と倍以上になること を見出し，米粒表層部の加熱糊化，粒全体に及ぶ澱粉結晶 構造の消失など粒構造の変化が吸水性を著しく改善させる ことを明らかにし，早炊き米の調理時間短縮に吸水性改善 
が大きく寄与していると考察した。

豊島ら ${ }^{8}$ は, 洗米条件, 蒸煮時間および蒸煮圧力を変え た蒸煮処理早炊き米について処理条件により食味が変化す ること, また，RVAの最高粘度が低下し最終粘度が増加 することを報告しているが，熱風処理あるいはレトルト処 理早炊き米の炊飯性に及ぼす研究はほとんどない。また, 市販早炊き米の炊飯時の加水量は加熱処理方法(蒸煮処理, 熱風処理，レトルト処理）によりそれぞれ異なっており, 経験的に定めているが学問的な検討は全くなされていな い. 本研究では, 製造方法の異なる早炊き米について吸水 性, 粒構造, テクスチャーなどの品質に及ほすす加熱処理の 影響について検討し，炊飯時に必要とされる水分量の差に ついても検討した.

\section{実験材料および実験方法}

\section{1. 供 試試料}

短時間蒸煮処理早炊き米 (以下 蒸煮処理品), 短時間 低温含気レトルト処理早炊き米（以下レトルト処理品） および短時間熱風乾燥処理早炊き米（以下 熱風処理品） の製造フローの概要を Fig. 1 に示す.

蒸煮処理早炊き米は前報と同じく 2003 年, 福島県産コ シヒカリ精白米（精白歩合 $92 \%$ ）を会津本郷農業振興公 社で $100^{\circ} \mathrm{C}, 10-15$ 分の短時間蒸煮処理したものを, レト ルト処理早炊き米は 2003 年, 岩手県産ひとめぼれ精白米 （精白歩合 92\%）を湿式無洗米処理後，愛知県内の企業で 最高温度 $110^{\circ} \mathrm{C} ， 30$ 分程度の含気（窒素置換）レトルト処 理したものを，熱風処理早炊き米はブレンド米（精白歩 合・産年産地不明）を短時間熱風処理した市販品（加熱条 件不明）を用い, 対照として 2003 年, 福島県産コシヒカ リ精白米（精白歩合 92\%）を使用した。

\section{2. 実験方法}

1 ) 試料の乾燥打よび粉砕

前報と同様に，それぞれの早炊き米試料は水分 14-15\% 程度になるよう予め室温 $\left(20-30^{\circ} \mathrm{C}\right)$ で，5-7 時間，通風

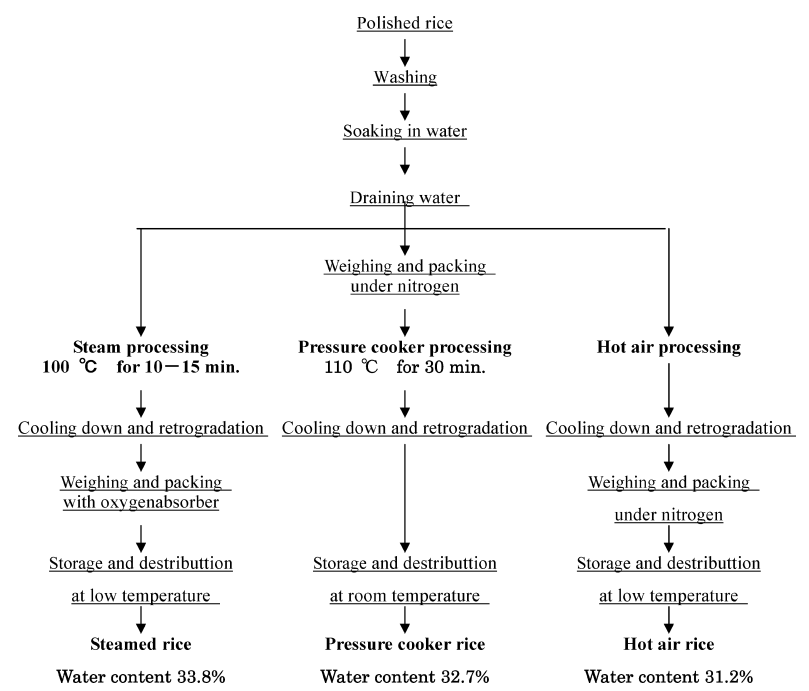

Fig. 1. Manufacturing procedures of three types of Hayadakimai.
乾燥した後，Tecator 社製 Cycltec 1093 Sample Mill $(0.5$ mm メッシュ装着) で粉砕し，X 線回折，粘度測定用試料とし た。なお，乾燥試料の粉砕は品温上昇防止のためドライア イス存在下で行った。また，糊化度測定用試料は(株)ット 科学研究所製ロール型粉砕器 TQ-100により粉砕した。

2 ) 吸水性試験

前報同様，酒造用原料米全国統一分析法 ${ }^{9}$ に準拠し行っ た。な㧍，初発の水分は常圧乾燥法 $\left(135^{\circ} \mathrm{C} ， 3\right.$ 時間）に より求めた。

3 ) 理化学的特性

走査型電子顕微鏡（SEM）による断面観察は前報同様, 脱水，固定化などの前処理は行わず，試料を真空デシケー ター中で十分に乾燥後，ピンセットで折り，その自然割断 面を銀蒸着した。観察は日本電子(㧣製走査型電子顕微鏡 JSM-820を用い, 加速電圧 5-10 kV で行った.

澱粉の結晶性はX 線回折により行った。前報同様，400 メッシュ以下に節別した粉砕試料を，相対湿度 75\%で一 晚調湿し(侏りガク製 Gaigerflex RAD- II C（線源 $\mathrm{Cu}$ ）を用 いて電圧 $40 \mathrm{kV}$, 電流 $40 \mathrm{~mA}$, スキャンスピード $2^{\circ} /$ 分で 測定した。

4 ）糊化特性

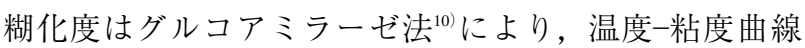
は前報同様，豊島ら ${ }^{11)} の$ 方法に準拠して Newport Scientific 社製 Rapid Visco analyzer RVA-3 D+ (RVA)を用い測定し た。測定条件は試料 $3.5 \mathrm{~g}$ (水分 $14 \%$ 換算) に水 $25 \mathrm{~mL}$ 加え, $50^{\circ} \mathrm{C}$ で 1 分間保持した後, $93^{\circ} \mathrm{C}$ まで 4 分間で昇温, $93^{\circ} \mathrm{C}$ で 7 分間保持, $50^{\circ} \mathrm{C}$ まで 4 分間で降温, $50^{\circ} \mathrm{C}$ で 3 分 間保持した。パドル回転数は開始後 6 秒間は $960 \mathrm{rpm}$ と し，それ以降は $160 \mathrm{rpm}$ とした。

5 ) 炊飯

炊飯にはタイガー魔法瓶社製マイコン電子炊飯器 JNL-F 550 (早炊きモード付き) を用いた。市販の早炊き米試料 $100 \mathrm{~g}$ にそれぞれ調理法で定められた所定の水分量（蒸煮 処理品, $100 \mathrm{~g}$; レトルト処理品, $136 \mathrm{~g}$; 熱風処理品, $130 \mathrm{~g}$ ）を加えた後，直ちに早炊きモードで炊飯（約 25 分） した．対象としてコシヒカリを網かごに取り，流水中で 1 分間洗米し，原料米重量の 1.5 倍（洗米中の吸水を含む） になるよう水を加え, 水温 $15^{\circ} \mathrm{C}$ で 60 分間浸漬後, 通常炊 飯モードで炊飯・蒸らし（合計約 45 分）を行った。

\section{6 ）物性測 定}

過剩な蒸気抜きを兼ねて炊飯米をプラスチック容器に移 し, 結露水の落下防止のため木綿布で上部を覆い, 室温 $25^{\circ} \mathrm{C} ， 1$ 時間放置した試料をテンシプレッサー（タケトモ 電機製 My Boy System）を用いて，岡留らの単粒法により 炊飯米の物性を測定した ${ }^{12,13)}$. 試料米 1 粒をプランジャー 径 $\phi 18 \mathrm{~mm}$ ，圧縮速度 $0.1 \mathrm{~mm} / \mathrm{s}$ で，低圧縮（25\%）拈よび 高圧縮（90\%）の二度の圧縮を繰り返し，定法通り硬さ (90\% 圧縮加重の積分值)，コシ (25\% 圧縮加重の積分值 と $90 \%$ 圧縮加重の積分值の比), 付着 (90\%圧縮後のプラ ンジャー戻りに要した負の加重の最大值), 粘り（90\%圧 
縮後のプランジャー戻りに要した負の加重の積分值）を求 めた。

\section{結果および考察}

\section{1. 吸 水特 性}

各試料の初発水分は対照品(コシヒカリ) $14.8 \%$ に対し, 熱風処理品, レトルト処理品, 蒸煮処理品の順で多くな り, 吸水後の加熱条件の差が水分に反映していた．水切り 後直ちに包装し水分の移行がほとんどないレトルト処理品 で 32-34\% (平均 32.7\%), 水切り後に蒸気加熱した蒸煮処 理品では蒸煮中の水分吸収のため 33-35\%（平均 33.8\%)

と高く, 逆に, 熱風処理品では水分が蒸散し易く $31-32 \%$

（平均 $31.2 \%$ ) と最も水分量が少なかった。 また，その外 観は対照品と比較し, いずれの早炊き米も表面に光沢があ り, 吸水加熱の影響により膨潤しており特に長径方向でそ の傾向が顕著であった。

これらを $15^{\circ} \mathrm{C}$ の冷水に 240 分間または, $50^{\circ} \mathrm{C}$ の温水に 60 分間浸漬したときのそれぞれの水分変化を Fig. 2 に示 した。浸漬温度 $15^{\circ} \mathrm{C}$ ではいずれの試料も 120 分でほぼ平 衡水分に達し, 対照品 $29.5 \%$, レトルト処理品, 蒸煮処理 品に差は認められず，それぞれ $38.7 \% ， 38.8 \%$ であった. 熱禹処理品は $34.8 \%$ で, 対照品とレトルト処理品, 蒸煮 処理品のほぼ中間であった。一方, 浸漬温度 $50^{\circ} \mathrm{C}, 60$ 分 間浸漬後の対照品の水分は $29.3 \%$ で $15^{\circ} \mathrm{C}, 120$ 分と同じ 值で浸漬水の温度による平衡水分量に差は認められなかっ た.一方, 早炊き米では, 熱風処理品 $45.4 \%$, レトルト処 理品 $54.7 \%$, 蒸煮処理品は炊飯米並みの $63.3 \%$ まで増加し ており，吸水速度もこの順で速くなった，蒸煮早炊き米の 吸水性には温度依存性があることは前報で明らかにした が, レトルト処理品あるいは熱風処理品においても吸水量 の増加, 吸水速度の上昇などが共通して認められ, 吸水性 の改善が早炊き米の炊飯時間短縮に共通に寄与しているこ とが示唆された. また, 熱風処理品, レトルト処理品, 蒸 煮処理品の吸水後の水分にはそれぞれ $10 \%$ 程度の差があ り, 加熱方法により粒表層での糊化層の形成, 澱粉の結晶 性の崩壊など粒構造に差があることが示唆された。
(A)

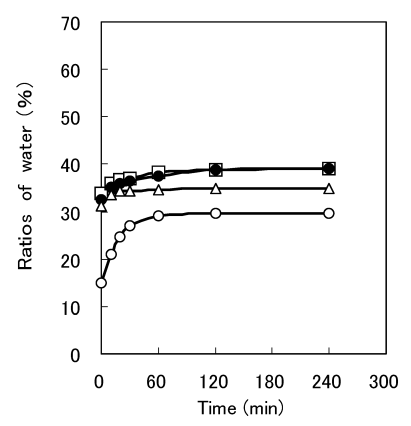

(B)

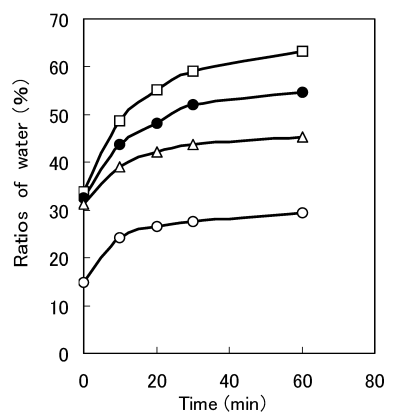

Fig. 2. Water absorption profiles of three types of Hayadakimai.

(A) Soaking at $15^{\circ} \mathrm{C}$, (B) Soaking at $50^{\circ} \mathrm{C}$. $\square$, steamed rice; pressure cooker processed rice; $\triangle$, hot air processed rice; $\bigcirc$, control (incooked rice).

\section{2. 粒構造の変化}

Fig. 3 に示したX 線回折パターンから明らかなように, 蒸煮処理品（D）は市販 $\alpha$ 米（E）のV 図形に類似し, 澱 粉の結晶構造はほぼ消失していた。一方, 熱風処理品（B) は穀類澱粉特有の A 図形を示し ${ }^{14)}$, その回折強度も対照品 (A) とほぼ同じで, 澱粉の結晶構造が維持されているこ とが明らかとなった。レトルト処理品 $(\mathrm{C})$ も A 図形を示 したが回折強度は対照品, 熱風処理品と比較し弱く, 結晶 構造が部分的に消失していると考えられた。また，グルコ アミラーゼ法による糊化度は対照品 $8 \%$, 熱風処理品 45\%, レトルト処理品 $73 \%$, 蒸煮処理品 $81 \%$ で加熱方法 により差があるものの, いずれの早炊き米も吸水後の加熱 処理により澱粉の糊化が進行していた.

早炊き米断面の SEM 観察結果を Fig. 4 に示した. 蒸煮 処理品（Fig. 4A）は前報同様に，粒中心部に向かって同 心円状に配向した澱粉粒を含む通常の細胞組織構造が確認 されたが(5), 表層から約 $100 \mu \mathrm{m}$ の幅で細胞構造が完全に 消失し非晶質化した糊化層が認められた。レトルト処理品 (Fig. 4B)の断面も蒸煮処理品同様に中心部の結晶構造, 表 層部の糊化層が確認された。一方, 熱風処理品 (Fig. 4C) の表層部には明瞭な糊化層はほとんど認めらず，粒構造に 及ぼす加熱処理の影響は蒸煮処理品, レトルト処理品より も小さいことが明らかとなった．著者らはSEM 観察では 細胞構造を完全に維持している蒸煮処理早炊き米粒中心部

（表層から重量比で 40\%を研磨で取り除いたもの）にお いても，X線回折では $\mathrm{A}$ 図形を示さず， $\mathrm{V}$ 図形になって おり, 水存在下での短時間加熱で中心部まで結晶性が消失 することを前報で明らかにした。

$\mathrm{X}$ 線回折による結晶構造の消失 (Fig. 3), 糊化度の上昇 および SEM 観察結果（Fig. 4）は良く一致し，粒構造の变

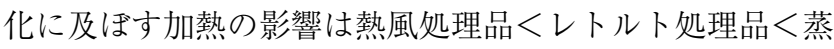
煮処理品の順に大きくなっていることが判明した. $50^{\circ} \mathrm{C}$, 1 時間浸漬後の水分量も熱風処理品 $<レ ト ル ト$ 処理品 $<$ 蒸 煮処理品順に増加しており, 吸水量の増加には粒構造の変 化（結晶構造の消失，糊化度，糊化層の形成）が大きく関

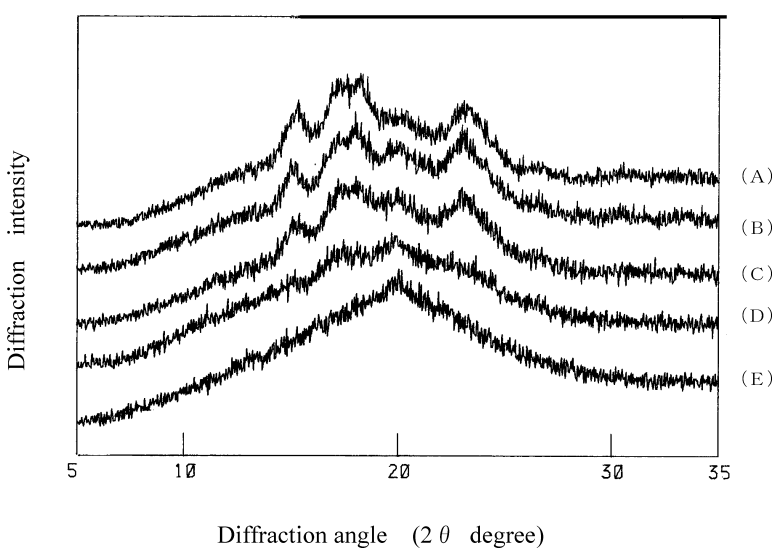

Fig. 3. X-ray diffraction patterns of three types of Hayadakimai.

(A) Control (uncooked rice), (B) Hot air processed rice, (C) Pressure cooker processed rice, (D) Steamed rice, (E) Dried gelatinized rice. 
(A)

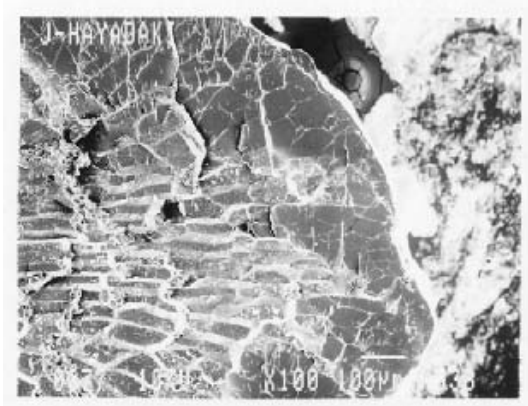

(B)

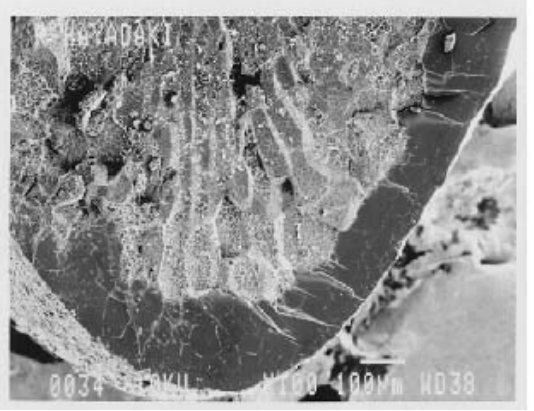

(C)

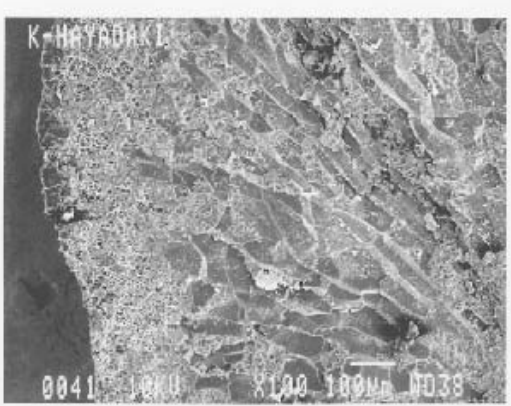

Fig. 4. Scanning electron microgams of three types of Hayadakimai.

(A) Steamed rice, (B) Pressure cooker processed rice, (C) Hot air processed rice. White bars represent $100 \mu \mathrm{m}$.

Table 1. Pasting properties of three types of Hayadakimai.

\begin{tabular}{|c|c|c|c|c|c|c|c|}
\hline \multirow{2}{*}{ Sample } & \multirow{2}{*}{$\begin{array}{l}\text { Temperature at } \\
\text { which viscosity } \\
\text { begins to rise }\left({ }^{\circ} \mathrm{C}\right)\end{array}$} & \multicolumn{2}{|c|}{$\begin{array}{l}\text { Maximum } \\
\text { viscosity }\end{array}$} & \multirow{2}{*}{$\begin{array}{l}\text { Minimum } \\
\text { viscosity } \\
\text { (cp) }\end{array}$} & \multirow{2}{*}{$\begin{array}{l}\text { Breakdown* } \\
\text { (cp) }\end{array}$} & \multirow{2}{*}{$\begin{array}{l}\text { Final viscosity } \\
\text { at } 50^{\circ} \mathrm{C} \\
\text { (cp) }\end{array}$} & \multirow{2}{*}{$\begin{array}{l}\text { Setback }{ }^{* *} \\
\text { (cp) }\end{array}$} \\
\hline & & (cp) & $(\min )$ & & & & \\
\hline Polished rice & $67-68$ & 4011 & 6.2 & 1777 & 2234 & 3012 & 1235 \\
\hline Hot air processing rice & $72-74$ & 3724 & 6.7 & 2241 & 1483 & 4096 & 1855 \\
\hline Pressure cooker processing rice & $72-73$ & 2279 & 6.8 & 1742 & 537 & 3152 & 1410 \\
\hline Steamed rice & $69-71$ & 3413 & 6.8 & 2006 & 1407 & 3496 & 1490 \\
\hline
\end{tabular}

${ }^{*}$ Maximum viscosity-Minimum viscosity. ${ }^{* *}$ Final viscosity at $50^{\circ} \mathrm{C}-$ Minimum viscosity.

与していることが示唆された。

結晶構造を持つ生澱粉では結晶ミセル内に水分はほとん ど侵入できず，吸水は非晶質部分および結晶表面のみが関 与すると報告されている ${ }^{16)}$. SEM 観察結果で粒表層部に 糊化層形成にあまり差がみられなかった蒸煮処理品とレト ルト処理品の吸水量の差は, X線回折結果で明らかとなっ た両者間の結晶性の差に起因し，熱風処理品が最も吸水量 が少ない原因は結晶性の消失が少なく，表層部での糊化層 形成も僅かなためと考えられる。

\section{3. 糊 化特 性}

RVA による温度一粘度曲線を Fig. 5 に, その特性值を Table 1 に示した。糊化開始温度は対照品の $67-68^{\circ} \mathrm{C}$ と比 較し, いずれの早炊き米も温度が上昇し, 蒸煮処理品で 69-71 ${ }^{\circ} \mathrm{C}$, レトルト処理品で $72-73^{\circ} \mathrm{C}$, 熱風処理品で $72-$ $74^{\circ} \mathrm{C}$ と 2- $6^{\circ} \mathrm{C}$ 上昇した. 最高粘度は $4011 \mathrm{cp}$ から $3724 \mathrm{cp}$ (熱風処理品), $3413 \mathrm{cp}$ (蒸煮処理品）と $10 \%$ 前後低下し ており，特にレトルト処理品では $2279 \mathrm{cp}$ と約半分にまで 低下した。 また，最高粘度到達時間も対照品の 6.2 分に比 べ，6.7-6.8 分と遅くなった。最終粘度は対照品（3012 cp） と比較し, 熱風処理品 $(4096 \mathrm{cp})$, 蒸煮処理品 $(3456 \mathrm{cp})$ では高い值を示したが，レトルト処理品は $3152 \mathrm{cp}$ と対照 品との間に大きな差はみられなかった。ブレークダウンは 対照品》熱風処理品 $\fallingdotseq$ 蒸煮処理品》レトルト処理品の, セットバックは対照品くレトルト処理品 $\fallingdotseq$ 蒸煮処理品 $<$ 熱 風処理品の順であった。

蒸煮処理早炊き米の最高粘度の低下および到達時間の遅 延，糊化開始温度の上昇は豊島ら ${ }^{8)}$ がすでに報告しており， 高橋ら ${ }^{17}$ は乾熱処理あるいはオートクレーブ処理した米粉 で最高粘度の低下, 糊化開始温度の上昇, ブレークダウン

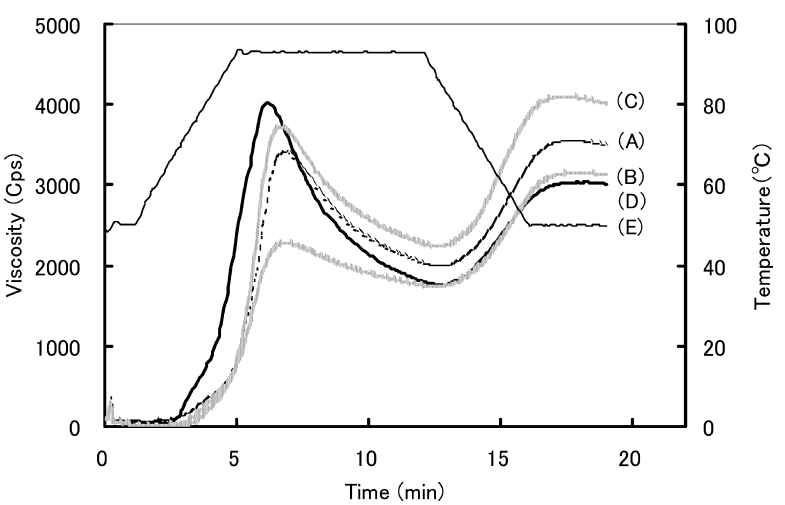

Fig. 5. RVA viscograms of three types of Hayadakimai.

(A) Steamed rice, (B) Pressure cooker processed rice, (C) Hot air processed rice, (D) Control (uncooked rice), (E) Temperature.

の減少など同様の現象を見出している。これは久下ら ${ }^{18)}$ 報告した糊化温度以下での長時間の湿熱処理によるアニー リング現象と同一で，水分共存下での糊化温度以上の加熱 処理においてもアニーリング現象が起きたと考えられた。

RVAによる温度一粘度曲線は米の銘柄により異なり最終 粘度, セットバックに大きな差があり，一般に最終粘度が 高く, セットバックの大きい米は老化しやすく食味が落ち るといわれている.今回比較した試料の銘柄は対象品と蒸 煮処理品がコシヒカリ，レトルト処理品がひとめぼれ，熱 風処理品がブレンド米とそれぞれ異なっており最終粘度, セットバックの相違が加熱処理条件によるものか銘柄の差 によるものかは明確にできなかった。

\section{4. 炊 飯 特 性}

豊島ら ${ }^{8)}$ はササニシキとコシヒカリのブレンド米から調 製した蒸煮処理早炊き米は原料米と比較し，炊飯米 (白飯) では硬くて粘りが弱く, 調味液と一緒に炊飯した（味付け 
飯）場合は精白米の硬さが増加し，粘りが低下するため早 炊き米と精白米の差は小さくなることを報告している．今 回比較検討した三種類の市販早炊き米は具材および調味液 と一緒に炊飯される炊き込みご飯としての用途が多く，具 材・調味液と早炊き米とをセットとして販売されているも のがある。また，白飯として炊飯する場合は硬さの増加， 粘りの低下を少なくする目的で加水量を多くして炊飯する ことを推奨している。

炊飯時の加水量は対照品では対原料重量比 1.5 倍である のに対し, 早炊き米では蒸者処理品は 1 倍, 熱風処理品は 1.3 倍, レトルト処理品は 1.36 倍で, 固形物換算で加水量 を比較すると, 精白米は 1.93 倍で蒸煮処理品は 2.02 倍で 大きな差はみられない。一方, 熱風処理品では 2.34 倍, レトルト処理品は 2.51 倍となり, 早炊き米は多加水条件 で炊飯が必要で, 特にレトルト処理品の加水が最も多かっ た。

調理法で定められた加水量で炊飯した 50 粒の炊飯米テ クスチャー測定值の分布を Fig. 6 に，特性值を Table 2 に 示した. Fig. 6 の横軸と縦軸の比は Table 2 のコシに, 縦 軸は硬さに相当する。対照米の分布が最も広く，早炊き米 では分布範囲は狭くなり，炊飯前の加熱処理は炊飯時の加 熱むらを減少させる効果が認められ，特にレトルト処理品 の分布が最も狭かった。レトルト処理品は袋に密閉した後
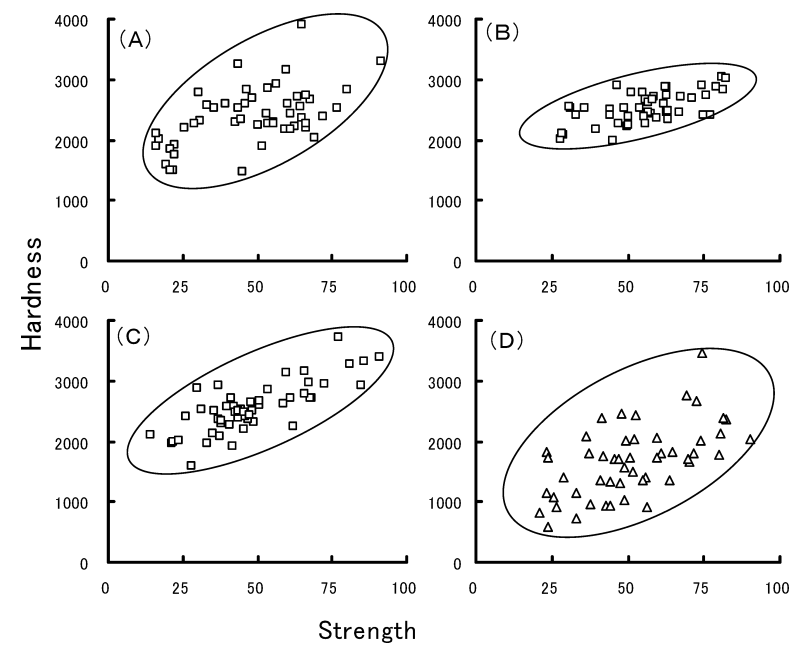

Fig. 6. Rheological properties of cooked grains of three types of Hayadakimai.

Each hayadakimai sample was cooked and rheological properties of respective grains were determined by Tensipresser. (A) Steamed rice, (B) Pressure cooker processed rice, (C) Hot air processed rice, (D) Control (uncooked rice).

Table 2. Rheological properties of three types of Hayadakimai.

\begin{tabular}{|c|c|c|c|c|}
\hline Sample & $\begin{array}{c}\text { Strength } \\
\text { (Koshi) } \\
\text { Ave. } \pm \text { SD* }\end{array}$ & $\begin{array}{c}\text { Hardness } \\
\text { (Katasa) } \\
\text { Ave. } \pm \text { SD }^{*}\end{array}$ & $\begin{array}{c}\text { Stickness } \\
\text { (Fuchakusei) } \\
\text { Ave. } \pm \text { SD }^{*}\end{array}$ & $\begin{array}{l}\text { Adhesiveness } \\
\text { (Nebari) } \\
\text { Ave. } \pm \mathrm{SD}^{*}\end{array}$ \\
\hline Polished rice & $0.16 \pm 0.031^{\mathrm{a})}$ & $45650 \pm 17234^{a)}$ & $-162 \pm 77.9^{a)}$ & $-4452 \pm 2840^{\mathrm{a})}$ \\
\hline Hot air processing rice & $0.09 \pm 0.026^{\mathrm{b})}$ & $76532 \pm 20307^{\mathrm{b})}$ & $-549 \pm 147.6^{b}$ & $-9685 \pm 2981^{b)}$ \\
\hline Pressure cooker processing rice & $0.11 \pm 0.017^{\mathrm{c})}$ & $83383 \pm 14810^{b)}$ & $-557 \pm 115.1^{\mathrm{b})}$ & $-7003 \pm 2354^{c)}$ \\
\hline Steamed rice & $0.10 \pm 0.018^{\mathrm{b}), \mathrm{c}}$ & $78616 \pm 19648^{\mathrm{b})}$ & $-470 \pm 112.1^{\mathrm{c})}$ & $-7764 \pm 3146^{c)}$ \\
\hline
\end{tabular}

*Standard deviation. Shoulder's alphabet means the result of Dankan's multiplex analysis. There is no significant difference between the same alphabet. And there are significant difference $(\rho<0.05)$ between different alphabets.
に加圧加熱することにより均一な加熱処理が可能となり， 安定した品質の早炊き米となったと考えられる。銘柄が異 なるため特性值を単純に比較することは危険であるが，い ずれの早炊き米も対照米と比較しコシがなく，硬く，付着 性，粘りともに大きい炊飯米になる傾向を示し，豊島ら ${ }^{8)}$ の報告のように調味液，具材などを含む炊き込みご飯等に 適性があると考えられる。豊島らはテクスチュロメーター を用いた炊飯米の物性測定結果より，早炊き米の粘りは小 さいと述べる一方，テンシプレッサーでの $90 \%$ 圧縮によ る粘りには差が認められないデー夕を示している，今回の 粘りが大きくなる結果とは一致しなかったが，使用した原 料米の銘柄が異なること, 測定方法が異なることがその要 因と考えられる。

米澱粉あるいは米粉は吸水加熱により体積が数十倍以上 に膨張するのに対し，米粒では細胞壁の制約を受け 2.5 倍 程度にしか膨潤できない ${ }^{19)}$ 。粒食を前提とした炊飯は澱粉 を包む細胞壁の加熱変化と細胞壁による制約を受けた澱粉 糊化の二つの現象が同時に進行する。豊島らは炊飯後の蒸 煮処理早炊き米の水分は多く，飯粒は澎潤し体積が多くな る (釜ぶえ) ことを見出しており，澱粉の膨潤を抑制する 細胞壁の機能が低下していることが示唆され，早炊き米で 最高粘度が低下する RVAの結果（Fig. 5）はこの考えと 一致する.

米は長期の保存によりへキサナールなどの発生，細胞壁 の架橋化およびタンパク質の SH から S-S 結合への酸化に よる硬さの上昇，澱粉分解酵素の活性低下による可溶性成 分の減少，遊離脂肪酸の澱粉への包接による膨潤抑制など を古米化の機構として森高は提案している ${ }^{20)}$. さらに，貯 蔵中の温湿度变化により細胞壁が吸脱湿を繰り返し，細胞 間の接続が弱く脆くなり，亀裂が入りやすくなるため，精 白時に砕粒米発生率が増加することが知られている。古米 の炊飯物性は浸漬時間の延長および加水量の増加，細胞壁 分解酵素 ${ }^{21)}$ ，プロテアーゼの添加 ${ }^{22)} に よ り$ 改善すると報告 されている。いずれの早炊き米も短時間加熱による細胞壁 の構造変化と部分的な糊化と冷却による再結晶化（老化） により細胞壁がダメージを受け，コシの減少，硬さの増加 を招いたと考えられる。特に，SEM 観察（Fig. 4）では大 きな差が認められなかった蒸者処理とレトルト処理の早炊 き米で，レトルト処理品は多加水炊飯が必要であり, RVA での最高粘度の低下は高温，加圧による澱粉を内在 する細胞壁，タンパク質の構造変化（架橋化， S-S 結合の 
増加）によると考えられ，早炊き米での多加水炊飯は古米 での多加水炊飯同様に，可食領域に炊飯米の硬さを調整す るためには必須であることが示唆された。

米飯の付着性および粘りは飯粒表層部に再吸収された可 溶性成分（オネバ）および米飯の水分量の影響が大きい. 早炊き米の炊飯は官能的に最も重視される硬さを基準とし た多加水となっているうえ，表層部を覆う糊化層（Fig. 4) が可溶化しオネバとなって再吸収されたため付着性, 粘り が増加したと考えられる。

\section{要 約}

短時間加熱処理された早炊き米は，対照米と比較し吸水 性が著しく改善され， $50^{\circ} \mathrm{C}$ の温水に 60 分間浸漬した後の 平衡水分量は蒸煮処理品 $63.3 \%$ ，レトルト処理品 $54.7 \%$, 熱風処理品 $45.4 \%$, 対照品 $29.3 \%$ の順で，吸水性の改善が 調理時間短縮に寄与していることが示唆された。結晶性の 消失㧍よび糊化度の上昇は蒸煮処理品が最も顕著で，続い てレトルト処理品, 熱風処理品, 対照品の順で, 平衡水分 量と澱粉の構造変化の間に相関が認められた。

レトルト処理品，熱風処理品は，対照品と比較し多加水 での炊飯が必要で，炊飯米の物性は共通して脆く，硬く, 粘りや付着性が強い傾向にあった，早炊き米は部分的な加 熱と冷却による澱粉の老化拧よび細胞壁構成成分の架橋 (古米化) が進行して㧍り, 古米同様の多加水炊飯が必要 で加圧加熱処理を受けたレトルト処理品ではその影響が顕 著で，炊飯に最も多くの加水量が必要であった。

\section{文献}

1 ）農林水産省総合食糧局，食糧需給表 (2004).

2 ) 農林水産省総合食糧局, 米麦加工食品生産動態等統計調査 年報 (2004)。

3 ）浅野幸紀，浅野幸紀：貯蔵飯の製造法. 特許第 1896720 号,
1986-7-1.

4 ）浅野幸紀，浅野幸紀：貯蔵飯の製造方法及びその装置。特 許第 3271028 号, 1993-7-20.

5 ）佐野讓二，佐野讓二：包装早炊き米の製造方法．特許第 2051484 号, 1988-11-2.

6 ）味の素株式会社, 加納英雄, 山崎勝利, 鳥羽 茂：常温流 通米飯の製造方法. 特許第 2754799 号, 1989-11-15.

7 ）小早川和也，大滝尚美，西田淑男，吉尾信子，前田 敢，久 松 眞, 谷口 肇：蒸煮処理早炊き米の諸性質. 日食工誌, 52，212-218（2005）。

8 ）豊島英親, 小野正博, 岡留博司, 河村 満, 吉崎 繁, 木村 俊範，大坪研一：早炊き米製造条件と食味特性.日食工誌, 46, 197-204 (1999).

9 ) 国税庁酒類総合研究所編：酒造用原料米全国統一分析法 (1996).

10）檜作 進：糊化と老化.「澱粉科学実験法」，鈴木繁男，中 村道徳編集，朝倉書店，東京，pp. 171-175 (1979).

11）豊島英親，岡留博司，大坪研一，須藤 充，堀末 登，稲 津 修，成塚彰久，相崎万裕美，大川俊彦，井ノ内直良， 不破英次：ラピッド・ビスコ・アナライザーによる米粉粘 度特性の微量迅速測定方法に関する共同試験. 日食工誌, 44, 579-584 (1997).

12）岡留博司，豊島英親，大坪研一：単一装置による米飯物性 の多面的評価. 日食工誌，43，1004-1011（1996）.

13）岡留博司，豊島英親，須藤 充，安藤郁男，沼口憲治，堀 末 登, 大坪研一：米飯 1 粒の多面的物性測定に基づく米 の食味評価. 日食工誌，45，398-407 (1998).

14）檜作 進：澱粉粒の構造.「澱粉科学ハンドブック」, 二國 二郎監修，朝倉書店，東京, pp. 25-34 (1977).

15）貝沼やす子：米の一般的性状.「調理科学講座 3 植物性食 品 I」，島田淳子，下村道子編，朝倉書店，東京，pp．2-6 (1994).

16）貝沼圭二, 八田珠郎：澱粉粒の構造と形態.「澱粉科学の 事典」，不破英次，小巻利章，檜作 進，貝沼圭二編，朝 倉書店，東京，pp. 58-73 (2003).

17）高橋 徹, 篠田和雄, 三浦 靖, 金 哲, 小林昭一 : 加 熱処理が米粉の物理化学的特性に及ぼす影響. 日食工誌, 49, 757-764 (2002).

18）久下 喬, 北村進一: 澱粉粒のアニーリング一温水処理と 湿熱処理一. 澱粉科学, 32, 65-83 (1985).

19）竹生新治郎：米の食味.「米の科学」, 竹生新治郎監修, 朝 倉書店, 東京, pp. 117-137 (1989).

20）森高真太郎：精白米の貯蔵中の品質変化. 日本醉造協会 誌，73，690-696 (1978).

21）渋谷直人：米の細胞壁の化学構造と品質. 日食工誌， 37 , 740-748 (1990).

22）渡辺道子：古米の食味特性の改善. 澱粉科学，40, 163-168 (1993). 